\title{
The Gastronomy of Tenggerese's Cangkriman-Sodoran Oral Literature
}

\author{
Sony Sukmawan ${ }^{1 *}$ \\ ${ }^{1}$ Universitas Brawijaya, \\ Malang, Indonesia \\ *sony sukmawan@ub.ac.id
}

Article History: Submitted on $4^{\text {th }}$ July 2020; Accepted on $23^{\text {th }}$ September 2020; Published on $31^{\text {th }}$ December 2020

\begin{abstract}
The diversity and uniqueness of Tenggerese cuisine is a small part of the complexity of gastro-ritual. So far there have not been many comprehensive studies on the gastronomy in Tengger, especially the one in Tenggerese rituals. This article is focused on the ways Karo ritual reveals the aspects of art, aesthetics, socio-culture, history, and science and knowledge. Using the perspective of gastronomic literature, this research found out that the sacredness of traditional Tenggerese cuisine is stabilized in the oral literary piece of Cangkriman. This oral literary piece, which falls into the category of puzzle, becomes an integral part of the performance of Sodoran dance. Sodoran dance in turn becomes an integral part of Karo festival. The symbols of mercy, generosity, thoroughness, detailedness, and ancestor veneration can be seen in the preparation and serving of ritual foods (sesaji [food offerings]) and foods for the participants (cooked rice, side dishes, and snacks) in Karo festival. The preparation and serving of Karo ritual foods show unique culinary aesthetics. The preparation and serving of foods, side dishes, and snacks, which are done by the village institution bethek-sinoman, show a social activity that is full of the value of gotong royong (mutual cooperation). Specifically the genealogy and embryology of the Tenggerese people are symbolized in the traditional snacks of pepes and pasung.
\end{abstract}

Keywords: Cangkriman, Sodoran, Karo, gastronomic literature

\section{ABSTRAK}

Keragaman dan keunikan bidangan Tengger adalah bagian kecil dari kompleksitas gastroritual. Sejaub ini belum banyak ditemukan kajian komprehensif yang berfokus pada gastro di Tengger, lebih-lebih Kajian yang menyoroti gastro dalam ritual Tengger. Artikel ini terfokus kepada bagaimanakah gastronomi ritual Karo mengungkapkan aspek seni, estetik, sosial-budaya, sejarah, dan ilmu pengetabuan. Dengan menggunakan 
perspektif gastronomi sastra, penelitian yang berlokasi di Desa Tengger ini menghasilkan temuan bahwa hidangan tradisional Tengger distabilkan kesakralannya melalui sastra lisan Cangkriman. Sastra lisan kategori teka-teki ini menjadi satu bagian utuh dengan pentas tari Sodoran. Tari Sodoran pun menjadi bagian tak terpisabkan dengan perayaan Karo. Simbol kemuraban, kedermawanan, ketelitian, kedetilan, dan penghormatan lelubur ditampakkan dalam penyiapan dan penyajian makanan ritual (sesaji) dan makanan santapan (nasi, lauk, dan jajanan) pada rangkaian Karo. Tata sesaji Karo juga mencerminkan sebuah estetika boga yang khas. Proses peramuan dan penyajian masakan dan jajanan oleb institusi bethek-sinoman menunjukkan sebuah aktivitas sosial yang penuh nilai kegotongroyongan. Secara khusus, sejarah geneologi dan embriologi manusia Tengger disimbolkan dalam kue pepes dan pasung.

Kata Kunci: Cangkriman, Sodoran, Karo, gastronomi sastra

\section{INTRODUCTION}

Karo festival is one of the important annual rituals in Tengger. The festival is important because (i) it reflects the history and identity of Tengger, (ii) it is the only feast day which the multi-religious Tenggerese community have, (iii) it is carried out the longest period of time, simultaneously, and in the most lively manner, (iv) its ritual structure is the most complex, and (v) it serves the most complete foods. The Tenggerese, regardless of their religions and beliefs, consider Karo as their feast day (riaya). Very early on the first day of Karo festival, Rakan Tawang ritual is performed. The ritual is aimed at letting the ancestors know that Karo festival celebration will start soon. Afterwards the tradition of Mblarai symbolically opens the festival, which is carried out lively and continuously for two weeks.

Before Karo festival starts, various food offerings in the form of quite complex dishes are prepared. The local cooks relied on for preparing the foods are bethek-sinoman. These local professionals work in a gotong-royong (mutual cooperation) manner and voluntarily. Bethek-sinoman work a shift system. Bethek activities start early on the day because they have to cook until around 9 at night, while the sinoman start working in the afternoon, through the night to do melekan (staying up all night), to the morning.

The diversity, uniqueness, and completeness of the foods prepared and served by bethek-sinoman are understandable because the feast day of Karo is celebrated once in a year. One example that represents the diversity, uniqueness, and completeness of Karo foods is a food offering that is called Seroa Selawe. Seroa Selawa is a complete and unique food offering that can be found in the Karo ritual of $W$ alagara. Seroa Selawe consists of five regions each of which consists of five takirs. The takir in Seroa Selawe is made of sugar palm leaf. The contents of Seroa Selawe are juwadah, ketan wilingan, pisang, ricikan, pasung, pepes, tetelan, and jenang koleh (traditional food made from sticky rice mixed with palm sugar). The number of each food is 25 . The word selawe 
(twenty five) symbolizes the number of the children of the Tenggerese' forebears Roro Anteng and Joko Seger.

The diversity and uniqueness of Tenggerese dishes as described above are a small part of the region's (gastro) ritual complexity. So far there have not been many comprehensive studies on the gastronomy in Tengger, especially the one in Tenggerese rituals. Existing writings, studies, and research projects on Tengger are generally focused on its rituals and traditions. It can be said that the ritual gastronomy in Tengger is a research area that is rich, open, and challenging.

Food in a ritual should be seen not only from their physical or material aspect, but also from their metaphysical aspect. In addition, ritual foods are related to aesthetics and art. Good observation will reveal that around foods there are the arts of dancing, drama, painting, sculpture, literature, architecture, and music (Endraswara, 2018). In Karo ritual, we can find dancing art, drama, poetic literature, singing art, narrative oratory, music, handicraft, weaving art, and culinary art. These arts altogether become a pillar that supports Karo tradition in particular and Tenggerese tradition in general.

Initial gastronomy studies tried to understand the complexity of dishes in the Karo ritual of Sodoran as a part of the Tenggerese culture (see Fossali, 2008; Montanari, 2006). Since the literary aspect of Karo festival is also important to study, subsequent studies used gastronomic literature as their approach. Gastronomic literature comprises the appreciation (understanding), expression (creation), and gastronomy study (analysis) of literary works with a culinary and food twist. In short, this study is the gastronomic literature one because it seeks to analyse foods as the subject and at the same time object of an aesthetical work, as a symbol of the seedbed of Life (see Endraswara, 2018). The study also tries to understand food natural symbols and philosophy in the performing literary work of Sodoran (see Endraswara, 2018).

Considering the background above, this study is aimed at finding out how the Karo ritual of gastronomy reveals the aspects of art, aesthetics, socioculture, history, and science and knowledge of the Tenggerese community. Meanwhile, this study on a series of activities in Karo ritual using the perspective of gastronomic literature comprises three domains, i.e. oral literature of gastronomy, art literature of gastronomy, and myth literature of gastronomy (see Endraswara, 2018). The perspective of oral literature of gastronomy is used because the main rituals in Karo festival, Sodoran dance and Cangkriman recitation, are in the form of oral literature. All the characteristics of oral literature can be found in Karo ritual (especially Sodoran ritual). Some of the characteristics are that oral literature has existence, that it has bearers, and that it has audience. The existence of oral literature in Karo ritual is its dance performances. The bearers are the dancers, musical instrument players, ritual helpers, Cangkriman reciters, and Karo narrative reciters. The community, owners, connoisseurs, or audience comprise the 
local people, invited figures or officials, and mass media personnel (Amir, 2013).

Art literature of gastronomy is also covered because the literary work of Sodoran is expressed in a performance. It can be said that Sodoran dance is a ballet, a drama symbolizing the origin and purpose of human life. Myth literature of gastronomy becomes the other scope since the performance of the literary work of Sodoran is actually an important step in the performance of Karo ritual. The performance of Sodoran visualizes and symbolizes the legend of Karo, a legend that has a strong influence on the beliefs, life principles, and identities of wong Tengger (the Tenggerese people). The other Tenggerese legend that has such a strong influence is the legend of Jaka Seger and Roro Anteng (the legend of Kasada).

\section{METHOD}

The paradigm of this research is ethno-gastronomic literature. This paradigm sees that foods are unique cultural products and belong to a certain ethnic group. The paradigm emphazises the knowledge of extrinsic (ethnic) literature. The philosophy of ethno-gastronomy becomes the base for emic and phenomenological-naturalistic approaches. Emic approach is used because this study incorporates informants' viewpoints in establishing data meanings. The approach focuses on meanings seen from the viewpoints of the society who own the culture being studied (Harris, 1999). Meanwhile, the phenomenological-naturalistic approach is used because data are real phenomena just the way they are without any treatment. Considering the paradigm and approaches above, it is determined that this research applies qualitative method for analysing data. The method is focused on the description of cultural facts and phenomena around the gastronomy in Tengger.

This research was conducted in the greater village of Tengger. The four parts of Tengger belong to the regencies of Malang, Pasuruan, Lumajang, dan Probolinggo. The majority of the villagers adhere to Hinduism and still hold tightly to the Tenggerese customs and traditions (Sutarto, 2008). The Tenggerese villages where the research was conducted are Argosari Village, Senduro Sub-district, Lumajang Regency; Wanatara Village, Sukapura Sub-district, Probolinggo Regency; Tosari Village, Tosari Sub-district, Pasuruan Regency; and Ngadas Kidul Village, Poncokusumo Sub-district, Malang Regency. The selection of these research locations was not carried out at random, but based on pragmatic considerations (see Sudikan, 2001).

The key informants in this research are ritual practitioners/reciters, art activists, tradition owners (pandita, legen, sepuh, sanggar), village elders, cultural practitioners/artists, and village officials. The ordinary informants are common villagers who are involved in every ritual procession.

Data were collected directly from the Tenggerese community and other stakeholders. As a gastronomic literary text, Cangkriman Kertijoyo inside 
the frame of Sodoran dance is a humanistic phenomenon. Therefore, it requires humanistic approach. Due to this, data were collected ethnographically through in-depth interviews, involved observations, and documentation.

Data analysis was carried out selectively and continuously until no new important information was obtained. The analysis of concrete data was started after data transcription was completed. Data obtained from the transcription were sorted by (i) opening oneself (the researcher) to what were happening in order that complete data could be obtained (open coding); (ii) breaking down, checking, examining, comparing, conceptualizing, categorizing, and organizing data that were neatly classified (axial coding); and (iii) explaining categories and conducting an in-depth analysis (display code) (Endraswara, 2018).

Data validity test was conducted by applying triangulation model or re-clarification with multiple data sources. Data triangulation was carried out by collecting other data with which the existing data were corroborated. Methods triangulation was conducted by comparing the methods of collecting data from observations, interviews, and documentation. Then, data were corroborated with informants to obtain confirmation (member check), consultation with experts was conducted, and peer reviews were carried out (Endraswara, 2018).

\section{FINDINGS AND DISCUSSION}

\section{The Immortalization of Tengger Offerings in Cangkriman}

Using Foucault's perspective on discourse as the fixation and stabilization of realities on a written text, Tenggerese offerings can be considered as a reality that is stopped and stabilized on texts used in Karo festival, especially the tradition of Cangkriman recitation. Of the tens of Tenggerese mantras, Cangkriman is the only sacred text that must not be memorized. The other texts have to be memorized from time to time by all the priest-shamans from their inauguration time in the night of Kasada (mulunan) throughout their term of service. It can be understood that the prohibition of the memorization of the sacred text of cangkriman has been responded by recording it in writing.

Memory (memorization-orality) and reading (writing-literacy) have had a special place from time to time. Sacred mantras, for instance, have been successfully created and conserved with the memorization technology of humans' oral civilization up to the present time. In contrast, the sacredness of Cangkriman in Tenggerese rituals is preserved with printing technology. Unlike the other sacred mantras of Tengger whose existence and development can be traced to the era of pre-Hindu (Walandit inscription), Cangkriman's origin is still unknown. However, there is a speculation that the creator is Ki Dada Putih, a forebear of the Tenggerese people, who was a priest from Majapahit (Hefner, 1985). He is considered as the king of kings 
of all the spirits, ancestors, and esteemed villagers in Tengger (Sukmawan, 2017).

The answer clues for the fifteen puzzles in Cangkriman Kertijoyo can be found in the set of food offerings and its infrastructure in any ritual in Tengger. The foods served in the offerings in sequence are (1) lemek, (2) damar, (3) godong ajang, (4) sego, (5) tumpeng, (6) bero, (7) panggang ayam, (8) takir kurung, (9) pepes, (10) juwadah, (11) jenang koleh, (12) tetelan, (13) pisang ayu, and (14) surub (Sukmawan, Rizal, \& Nurmansyah, 2018). How the set of offerings and its infrastructure provide answer clues for the puzzles is explained in the following.

The answer to the first puzzle is ndemek-ndemek lemek (touching a tablecloth). Lemek means 'tablecloth'. Whatever the sajen (offerings) is, there must be a piece of lemek. The philosophical explanation is that everything in the universe must have a base. It can be said that lemek symbolizes the earth. The answer to the second puzzle is dalu or damar. Damar means 'lamps for lighting'. Lighting is needed to brighten human life or to have a smooth life, which means earning a good livelihood easily. Likewise, it is expected that human mind can be brightened (guided) by the useful knowledge about good and bad things. The answer to the third puzzle is ajang malang. Ajang malang is a kind of dandanan/banten/sesaji (food offerings), which means that in the life of every human, there must be obstacles. Life is always full of twists and turns. Every human must face such a situation. Because of this, it is expected that he/she never forgets to pray for a life that is free from obstacles.

Then, the answers are provided in sequence: (i) sego (cooked rice), which means the hope that humans will earn a livelihood easily; (ii) tumpeng - its cone shape resembles the shape of a mountain, which symbolizes welfare and prosperity; (iii) berah (grain), which symbolizes seeds of life or the continuity of life; (iv) roast chicken as the symbol of harmony; the wings, head, and legs of the roast chicken are tied together; this means that we should not discriminate between the rich and the poor or between the superior and the subordinate; in order that humans can be 'ayam' (chicken) or ayem (peaceful), all humans have be considered as being equal; (v) takir kawnng, which means 'entirety'; this means that when organizing our mind, we have to be conscientious and must not be careless; (vi) pasung-pepes, which symbolizes lingga and yoni; (vii) juwadah, which symbolizes the process of creation.

\section{Exploring Art, Socio-Culture, History, and Science and Knowledge through the Lens of Gastronomy}

Understanding the procession of Karo ritual from the perspective of gastronomic literature means uncovering the art, aesthetics, cultural symbols, social activities, and even science and knowledge of the Tenggerese (see 
Endraswara, 2018). With the perspective, the Tenggerese history may also be revealed (Endraswara, 2018: 28-29). Basically each of the aspects revealed by the approach of gastronomic literature cannot stand alone. Each aspect is a network of meanings and all of them form a whole of interconnected meanings. Each aspect is described in the following.

\section{a. Revealing Cultural Symbols}

A cultural symbol in the form of refined state is shown in the symbolic movement of Sodoran dancers. Sodoran dance consists of three scenes, namely papakan, adu sodor, and salipan. Papakan movement portrays a meeting between a man and a woman. Adu sodor movement portrays an intimate relationship between a man and a woman. Meanwhile, salipan movement portrays humans' life journey. All these modest movements are performed with strong emotions. In the section of pecah sodor, the overflow of any emotions - sadness, being touched, excitement-explodes with the cry of the dancers. These emotional modest dances display the values of human existence wrapped up in symbolic-euphemism.

The symbols of mercy and generosity are shown in the preparation and serving of the ritual food (sesaji) and food for the participants (cooked rice, side dishes, and snacks) in the series of activities in Karo ritual, from Mblarai, and Santi, through Leliwet, to Bawahan. The sesaji that may be eaten by humans is the sesaji of manusia yadnya. The sesaji shows thoroughness and detailedness in its preparation and serving. Each group of sesajen (ritual foods) is given a name based on its composition. In this section, descriptions are focused on meanings of the group of Pras ritual foods. The group consists of five types, namely Pras Goreh, Pras Petula, Pras Tebusan, Pras Among, and Pras Semoa.

Each type of Pras basically has the same composition of constituent elements. The elements are usually tumpeng, pasung, pepes, bera, kulup, tetelan, wilingan, juwadah abang, putih, ireng, pangkon, and panggang ayam (roast chicken). The five types of Pras become the base for the ritual foods in Karo ritual. What distinguishes one Pras from another is the number of constituent elements in each round, flat container of tempeh and the addition of other elements, such as kembang gubahan and ucet which are served in certain types of Pras only.

\section{b. Revealing Social Cohesion}

Tengger is a cultural landscape thriving with noble values adopted by the Tenggerese community and manifested through the performance of traditional rituals (Hamida, 2013). In this landscape, there are spirit, values, pluralism messages, multiculturalism, tolerance, mutual cooperation, unity, and social wholeness (Haliim, 2017; Haryanto, 2014; Nurcahyono \& Astutik, 2018; Sukmawan \& Febriani, 2018). Behind the unity of the Tenggerese community, there is diversity which becomes the pillar supporting the 
wholeness of the community. The diversity is formed by, among others, the richness of traditional rituals (for instance, slametan), the various religions adhered by the Tenggerese, and their various professions.

The diversity in the Tenggerese community does not become an obstacle to the efforts to develop harmony and strong solidarity in the community. Wirutomo, et al. (2015) stated that pluralism and/or diversity often triggers attention because people may relate it to conflicts among social groups and social disintegration. This means that diversity in the community has the potential to trigger conflicts, be it personal conflicts or communal conflicts. However, this is not the case with the Tenggerese community. Up to now, the social wholeness, unity, and solidarity in the community have still been maintained well. In the community, diversity is not considered as a source of injustice, but a social asset that has to be preserved.

The villagers in Mororejo adhere to different religions, but they can live in harmony. During the rituals of Entas-entas and Karo, both Muslims and Hindus help each other. I am a Hindus, but I follow the ceremonies held by my uncle who is a Muslim, because it is indeed our (Tenggerese) tradition to follow each other's ceremonies and help each other in holding them.

(Interview with Mr Ismawan, 31 years old)

What the informants says above implicitly shows that the performance of slametan in Tengger is a part of the Tenggerese tradition. The performance of slametan involves not only certain community groups, but also the whole community groups in Tengger. Furthermore, slametan rite becomes a space for the Tenggerese to develop harmony. This is in line with Suseno's opinion (1993) that in slametan there are the most salient values upheld by the Javanese including the Tenggerese, namely the values of togetherness, neighbourliness, and harmony. This shows that slametan rite is a very important capital for the Tenggerese community to develop social interaction.

\section{c. Exploring History}

The ethnogenealogy of the Tenggerese ethnic group can be traced to Ajisaka, a forebear of the Tenggerese who in the legend of Karo was enthroned in Medang Kamulan. The feast day of Karo is actually a form of respect for the service and heroism of the Tenggerese forebears. The Tenggerese people believe that Ajisaka and his two servants, Setya and Setuhu, did not only exist and live in the legend of Karo, but also ever existed and lived in the area of Tengger in the past. They are the pioneers (besides Joko Seger-Roro Anteng) who started the lineage of the Tenggerese ethnicity. Seen from the perspective of graph-genealogy, the twenty Javanese alphabets are a chant of poetry lines of Ajisaka as a form of respect for the 
loyalty, sincerity, and sacrifice of Setya and Setuhu. Hanacaraka is "there were messengers'; datasawala is 'disputed each other'; padajayanya is 'both were equally powerful"; and magabatanga is 'both fell'.

From the perspective of embryology, studying Karo ritual means revealing the origin or the creation of all human beings, not only the Tenggerese human beings. The battle between Setya and Setuhu to fight over and defend Sarutama heirloom in the legend of Karo/Ajisaka symbolizes intromission. Setyo is the symbol of men and Setuhu is the symbol of women. Specifically Sodoran dance is the euphemistic symbol of the meeting between an egg cell and a sperm cell during intromission.

At least the genealogy and embryology above are symbolized in the unique Tenggerese snacks of kue pepes and pasung. These two sacred snacks are always served in the sesajen of any ritual. On ordinary days, the Tenggerese villagers are forbidden from making the snacks, which become the metasymbols of yoni and lingga.

\section{d. Reading Science and Knowledge}

Terrestrial questions in Cangkriman Kertijoyo show the cosmological awareness of the Tenggerese of four space sides to understand the realities of West-East and North-South. The mention of 18 place names (cities, subdistricts, villages, and regions), namely Wonorejo, Kenongo, Nggedangan, Puspo, Baledono, Watu Panggang Sate, Mungal, Ngijo, Gonong Wowong, Sepedang, Pakel, Posong Tepes, Bangil, Ngopak, Pasuruan, Suroboyo, and Sidoarjo, convincingly shows that geographical knowledge and understanding underlie the emergence of oral literature. Seen from the opposite way, oral literature contains geographical knowledge. Cangkriman Kertijoyo is basically a small description of social science questions. The understanding of localities is translated into the literary work very concretely, modestly, and contextually.

Food service is reflected in the technique of positioning sesaji (ritual foods) besides social science. Ayam mancawarna, caru mancasata, liwet, cecepan caru, and tumpeng kuning, for examples, are positioned in certain places. Banyu kurung, gedang ayu tayupan isor, gedang ayu tayupan nduwur, pras semoa sayud, ajang malangan, galang, roahan, and pras petula are placed in front of the priest shaman. Meanwhile, gedang ayu roaban is placed at the right and left sides of the priest shaman.

The placing of pras among is different. This sesaji intended to amongamong (to 'protect' human soul and body) is placed in Sanggar Surya together with pras goreh, petra pesaksi, beras pitrah, wakul, suruh agung, suruban, sudang, pras tebusan, and manden. Then, pras sesa pertiwi, bentung piti, ajang tlewer and pras sesa gangga are placed for a moment at Sanggar Surya Bawah. Meanwhile takir jangan, sega lungguh, tumpeng, sega lungguh ketan, and takir janur are placed in Bale Banjaran Sari.

What are the function and meaning of sesaji? Informed by gastrosophy, the philosophical study on foods in various human needs including the ritual need (Endraswara, 2018), the function and meaning of 
sesaji can be described as follows. The function of pras tebusan is to redeem all wrongdoing. Pras goreh is intended to be food presented for the forebears safeguarding the water springs. The composition of pras goreh is always added with a constituent element of the other pras, i.e. kembang gubahan. Pras among is used to respect the invited forebears, so that they will feel respected and calm.

As to panggang ayam (roast chicken), this ritual food can be replaced with panggang mas. This pras is made of chicken that is roasted or scrambled eggs of free-range kampung chicken. The replacement of chicken with eggs implies a moral meaning that cheaper stuff can be used as a way to minimilize pressure from a certain requirement. Philosophically panggang ayam is the symbol of the presenter of the Pras that has been prepared and served. Eggs may be used to replace chicken due to the belief that later the eggs will become chicken.

With regards to pasung, it is a kind of conical wet cake made of rice flour. Banana leaf formed into a cone is used to shape the cake. To the Tenggerese community, the philosophical meaning of pasung is "when already 'fit', carried on", which means that when the time has come to someone, it is time to 'carry him/her to the tomb. After pasung, we can find bera and kulup. Bera and kulup are always placed side by side. Bera is a kind of food the main ingredient of which is big bean pieces. Kulup is a kind of food with cabbage leaves as the main ingredient. Philosophically both items have the same function. They are used to ward off the evil forces of Buta Kala.

Another philosophical meaning is revealed by the ritual food of tetelan. This dish made of finely ground sticky rice has an intact and round shape. This shape symbolizes obedience to what has been ordered. Wilingan is a pras element that is paired with tetelan. Wilingan is made of white sticky rice that is gripped and wrapped in banana leaf. The name of wilingan is taken from the Javanese word welingan/wilingan, which means 'advice' or pitutur (another Javanese word). Another cake is juwadah. In the pras arrangement, there are always three types of juwadah of different colours, i.e. juwadah abang (red), juwadah putih (white), and juwadah ireng (black). Juwadah abang is made of white corn flour and coloured red. Philosophically, juwadah abang symbolizes mother. Junadah putih is made of white corn flour without the addition of any colour and symbolizes father. Juwadah ireng is made of the same ingredient and coloured blackish blue. The last offering from which we can uncover a philosophical meaning is pangkon. Pangkon is a bunch of bananas that is still attached to its base. Philosophically, pangkon means 'supporting base'. Pangkon functions as a lap on which an arrangement of ritual foods is placed. It is placed on the front side of the round, flat container of tempeh.

Besides meanings related to the names and shapes of the constituent elements of pras, there are also meanings related to the number of each pras element in one tempeh. The number 2 symbolizes the creation of all things on earth that are in pairs and have two sides. The number 9 symbolizes nine holes on human body which become the sources of evil desires. To save 
humans from any evil desires originating from the holes, Pras Tebusan is made for redemption. The number 3 symbolizes the importance of the nurture of proper thinking, speaking, and behaving.

\section{CONCLUSION}

The sacredness of traditional Tenggerese dishes has been stabilized in the oral literary piece of Cangkriman. This oral literary piece, which falls into the category of puzzle, becomes an integral part of the performance of Sodoran dance. Sodoran dance in turn becomes an integral part of Karo festival. The symbols of mercy, generosity, thoroughness, detailedness, and ancestor veneration can be seen in the preparation and serving of ritual foods (sesaji (offerings)) and foods for the participants (cooked rice, side dishes, and snacks) in Karo festival. The preparation and serving of Karo ritual foods show unique culinary aesthetics. The preparation and serving of foods, side dishes, and snacks, which are done by the village institution of bethek-sinoman, show a social activity that is harmonious and full of the value of gotong-royong (mutual cooperation). Specifically the genealogy and embryology of the Tenggerese are symbolized in the traditional snacks of pepes and pasung. In short, Tenggerese foods reveal the art, aesthetics, socio-culture, history, and science and knowledge of the Tenggerese community (Mustapa \& Supratno, 2018).

Finally, it is hoped that the findings of this study may introduce the identities of Tenggerese foods, especially the ones related to Tenggerese rituals; help develop the pride of national identities; and help open a wider horizon of gastronomic literature and its benefits to humanity.

\section{REFERENCES}

Amir, A. (2013). Sastra Lisan Indonesia. Yogyakarta: Andi.

Endraswara, S. (2018). Metodologi Penelitian Gastronomi Sastra. Yogyakarta: Textium.

Fossali, P. B. (2008). Seven Conditions for the Gastronomic Sciences. Gastronomic Sci, 4(8), 54-86.

Haliim, W. (2017). Identitas Wong Tengger Masyarakat Desa Ngadas: Refleksi Kebangsaan Atas Degradasi Identitas dan Persatuan Nasional Indonesia. Proceeding AMIPEC, 2(2).

Hamida, L. (2013). Sosialisasi dan Kebijakan atas Keberagaman Bahasa pada Masyarakat Tengger Jawa Timur: Sebuah Fenomena Kearifan Lokal. International Seminar "Language Maintenance and Shift III," 267. Semarang.

Harris, M. (1999). Theories of culture in postmodern times. Maryland: Rowman Altamira.

Haryanto, J. T. (2014). Kearifan Lokal Pendukung Kerukunan Beragama pada Komuntias Tengger Malang Jatim. Analisa: Journal of Social Science and Religion, 21(2), 201-213. 
Hefner, R. W. (1985). Hindu Javanese: tengger tradition and Islam. New Jersey: Princeton University Press.

Montanari, M. (2006). Food is culture. New York: Columbia University Press.

Mustapa, R. S., \& Supratno, H. (2018). Sastra Kuliner sebagai Sarana Pendidikan Karakter (Analisis Novel Gerimis Di Arc De Triomphe Karya Nunik Utami). Didaktik: Jurnal Imiah PGSD STKIP Subang, 4(2), 279290.

Nurcahyono, O. H., \& Astutik, D. (2018). Harmonisasi Masyarakat Adat Suku Tengger (Analisis Keberadaan Modal Sosial Pada Proses Harmonisasi Pada Masayarakat Adat Suku Tengger, Desa Tosari, Pasuruan, Jawa Timur). Dialektika Masyarakat: Jurnal Sosiologi, 2(1), 1-12.

Sudikan, S. Y. (2001). Metode penelitian kebudayaan. Surabaya: Unesa Unipress.

Sukmawan, S. (2017). Leluhur Tengger: Kehadiran Psikis Sang Penjaga Gerbang Kosmis. Makalah Seminar Nasional Tradisi Lisan, 14.

Sukmawan, S., \& Febriani, R. (2018). Folklor Tengger: Literasi Harmoni Budaya, Instrumen Pendidikan, Konservasi, dan Kewirausahaan. Seminar Internasional Riksa Babasa, 739-750.

Sukmawan, S., Rizal, M. S., \& Nurmansyah, M. A. (2018). Green Folklore. Universitas Brawijaya Press.

Suseno, F. M. (1993). Etika Jawa: Sebuah analisa falsafi tentang kebijaksanaan bidup Jawa. Jakarta: Gramedia.

Sutarto, A. (2008). Kamus budaya dan religi Tengger. Jember: Lembaga Penelitian, Universitas Jember.

Wirutomo, P. (2015). Sistem Sosial Indonesia. Jakarta: Penerbit Universitas Indonesia. 